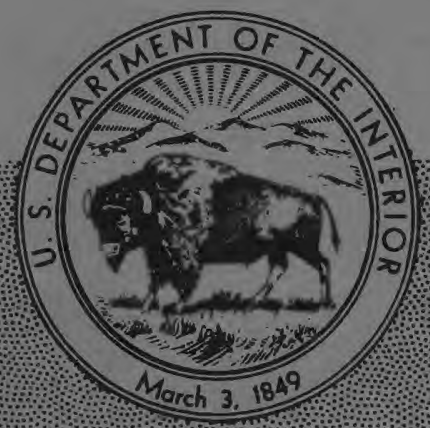

\title{
FLUVIAL SEDIMENT IN
}

\section{WHITEHEAD WATERSHED AND}

\section{WHITEHEAD RESERVOIRS}

NEBRASKA

\section{April 1955 to September 1956}

Prepared in cooperation with the U. S. Department of Agriculture, Soil Conservation Service and the U. S. Department of Commerce, Weather Bureau 


\author{
UNITED STATES DEPARTMENT OF THE INTERIOR \\ FRED A. SEATON, Seeretary \\ GEOLOGICAL SURVEY \\ Thomas B. Nolan, Director
}

GEOLOGICAL SURVEY CIRCULAR 406

\title{
FLUVIAL SEDIMENT IN WHITEHEAD WATERSHED AND WHITEHEAD RESERVOIRS, NEBRASKA
}

\section{April 1955 to September 1956}

By J. C. Mundorff and P. R. Jordan

Prepared in cooperation with the U. S. Department of Agriculture, Soil Conservation Service and the U. S. Department of Commerce, Weather Bureau. 


\section{CONTENTS}

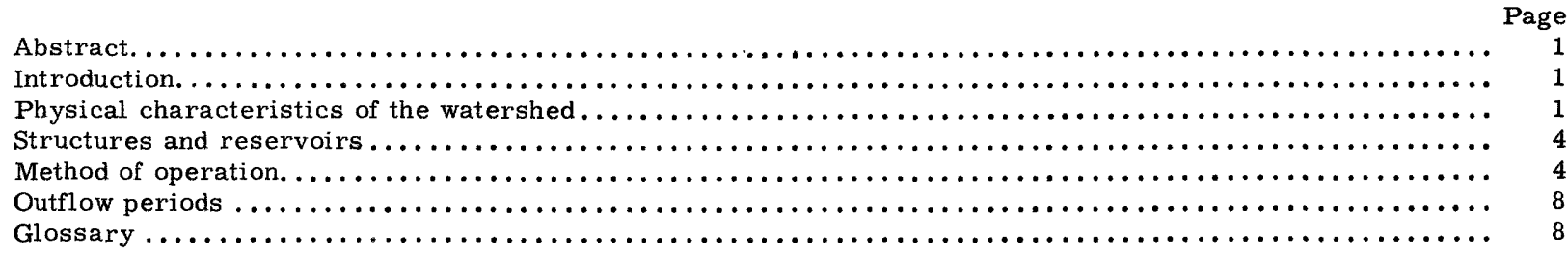

Page

8 8

\section{ILLUSTRATIONS}

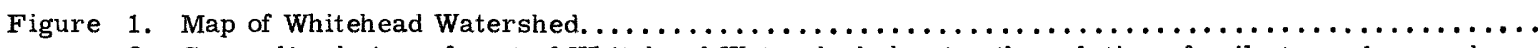

2. Generalized view of part of Whitehead Watershed showing the relation of soils to geology and

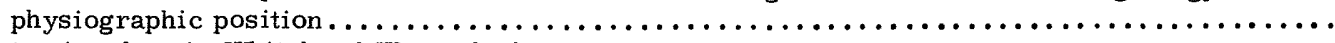

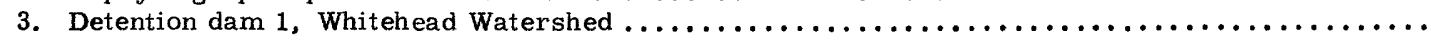

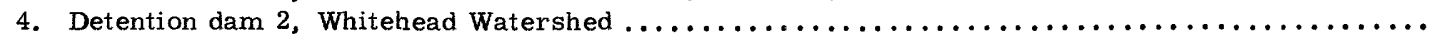

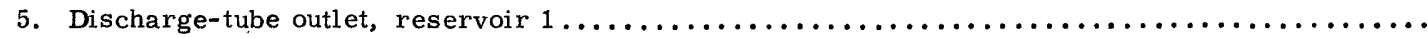

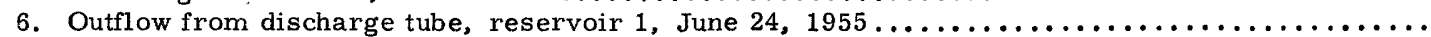

7. Vertical stack of automatic suspended-sediment samplers at trash rack, reservoir $1 . . . . . . .$.

8. Partly submerged vertical stack of automatic suspended-sediment samplers at trash rack,

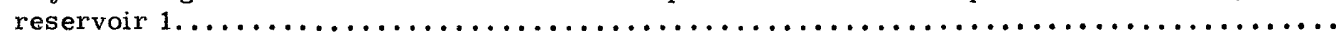

9. Water discharge, accumulated rainfall, and suspended-sediment concentration, reservoir 1 ,

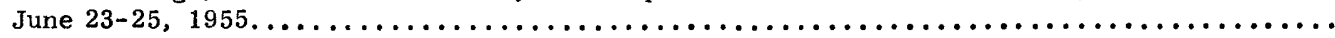

10. Reservoir gage height, accumulated rainfall, and suspended-sediment concentration, reservoir

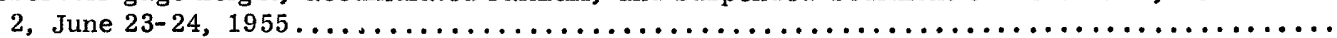

11. Water discharge, accumulated rainfall, and suspended-sediment concentration, reservoir 1 ,

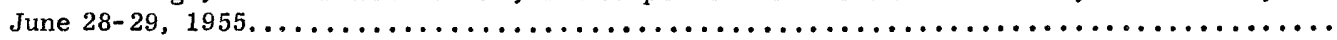

12. Water discharge, accumulated rainfall, and suspended-sediment concentration, reservoir 1 ,

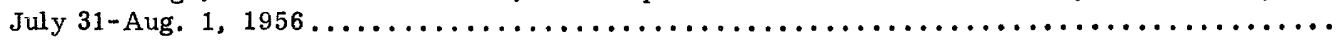

13. Water discharge, accumulated rainfall, and suspended-sediment concentration, reservoir 1 ,

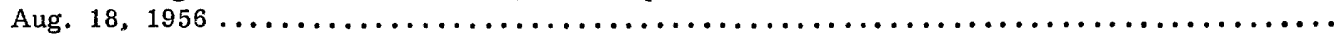

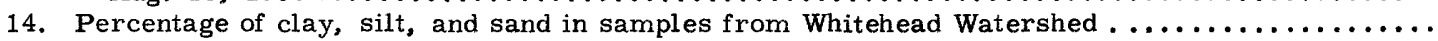

15. Relationship of particle size to suspended-sediment concentration of inflow samples ...........

\section{TABLES}

1. Area and capacity of reservoir 1 from survey of March 1955

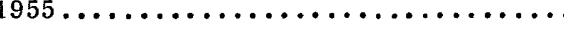

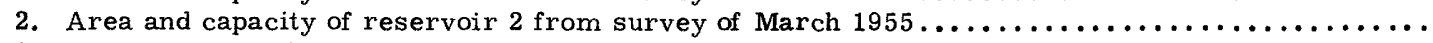

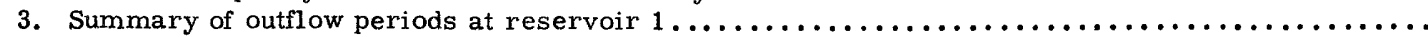

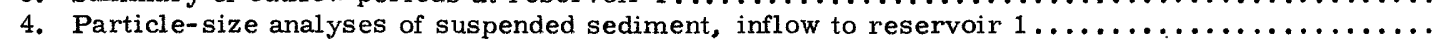

5. Particle-size analyses of suspended sediment, inflow to reservoir $2 \ldots \ldots \ldots \ldots \ldots \ldots \ldots \ldots$

6. Particle-size analyses of suspended sediment, outflow from reservoir $2 \ldots \ldots \ldots \ldots \ldots \ldots \ldots$

7. Particle-size analyses of suspended sediment, outflow from reservoir $1 \ldots \ldots \ldots \ldots \ldots \ldots \ldots$

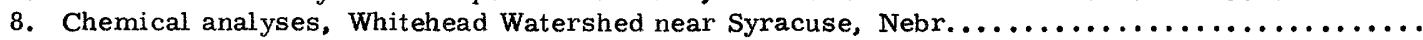




\title{
FLUVIAL SEDIMENT IN WHITEHEAD WATERSHED AND WHITEHEAD RESERVOIRS, NEBRASKA
}

\author{
April 1955 to September 1956
}

\author{
By J. C. Mundorff and P. R. Jordan
}

\begin{abstract}
This report gives information on the physical characteristics of Whitehead Watershed and on the characteristics of the suspended sediment transported into and discharged from the reservoirs. Selected periods of significant runoff and outflow from April 1955 to September 1956 are discussed.

Particle-size distribution of inflow and outflow samples indicates that all the sand entering reservoir 1 is trapped and that most of the sand entering reservoir 2 is trapped.

Results of chemical analyses of water samples and a comparison of suspended-sediment size analyses in native water and in distilled water with dispersing agent indicate that significant sediment flocculation may occur in the reservoirs.
\end{abstract}

\section{INTRODUCTION}

The study of fluvial sediment in Whitehead Watershed is part of a nationwide investigation of the trap efficiency of detention reservoirs. The Geological Survey is cooperating with the Soil Conservation Service in the work. The sediment investigation in Whitehead Watershed was directed by P. C. Benedict, regional engineer. D. M. Culbertson, area engineer, supervised field operations, compilation of data, and preparation of this report.

Records of water discharge were furnished by $D$. D. Lewis, district engineer. Records of precipitation were obtained in cooperation with the U. S. Weather Bureau.

\section{PHYSICAL CHARACTERISTICS OF THE WATERSHED}

Whitehead Watershed is in the central part of Otoe County, Nebr. (Seefig. 1.) The watershed is part of the dissected till plains of eastern Nebraska. The drainage area is approximately 495 acres.

Total relief within the drainage area is about 95 feet. Slopes generally are 4 to 12 percent and range from 100 to 800 feet in length. Figure 1 shows the shape of the watershed and the locations of dams 1 and 2, stabilization structures, two precipitation gages, and sediment sampling points.

Deposits of Pleistocene age mantle the watershed. Peorian loess, of late Pleistocene age, forms a. nearly continuous mantle over the eastern half of the area and is on divide areas and upper slopes in the western half of the area. Loess of the Loveland formation, which underlies the Peorian loess stratigraphically in this southeastern Nebraska area, is not exposed to any significant extent. Kansan till, also of Pleistocene age, is generally exposed on moderate to steep slopes in the western part of the watershed. The Kansan till, which is stratigraphically lower than the Peorian loess and the Loveland formation, generally is found topographically lower than these formations. Late Pleistocene to Recent alluvium mantles the small, narrow bottomland areas.

Soil development in the watershed varies mainly with parent material, physiographic position, and slope. Because climate and vegetation in this small drainage basin are homogeneous, they are relatively unimportant determinants of profile differences. Soils developed on loess are predominant in the eastern half of the area and grade into mainly glacial-till soils in the western part of the area. Slope, infiltration rate, soil permeability, and parent material may vary within small areas. Severe erosion has exposed the $B$ horizon in small areas of steeply sloping land.

A soil survey of Otoe County, Nebr., 1/ indicates that 61.6 percent, or about 305 acres, of the watershed is occupied by soils of the Sharpsburg series, which are developed on Peorian loess. Of the 305 acres, about 155 acres is Sharpsburg silty clay loam; 112 acres is Sharpsburg silty clayloam, rolling phase; and 38 aeres is Sharpsburg silty clay loam, eroded rolling phase. About 29.3 percent, or 145 acres, of the watershed is occupied by soils of the Carrington series, which are developed on glacial till. Of the 145 acres, about 5 acres is Carrington clay loam; 125 acres is Carrington clay loam, eroded rolling phase; and 15 acres is Carrington loam, croded rolling phase. Soils of the Burchard-Carrington complex, developed on glacial till, occupy about 2.0 percent of the watershed. The Judson-Wabash complex, developed on colluvial-alluvial material, occupies about 7.1 percent of the watershed.

Figure 2 shows the relation between soils, parent material, physiographic position, and slope in Whitehead Watershed.

Most of the drainage area is under cultivation; corn, sorghum, oats, and wheat are the main crops. Much of the steeply sloping land is in native grass or is seeded to grasses and legumes, and small areas of native grass are along the major channels. Nearly all the minor drainageways have been seeded to grass to prevent gully formation.

1/ U. S. Department of Agriculture, 1950, Soil survey of Otoe County, Nebr. 


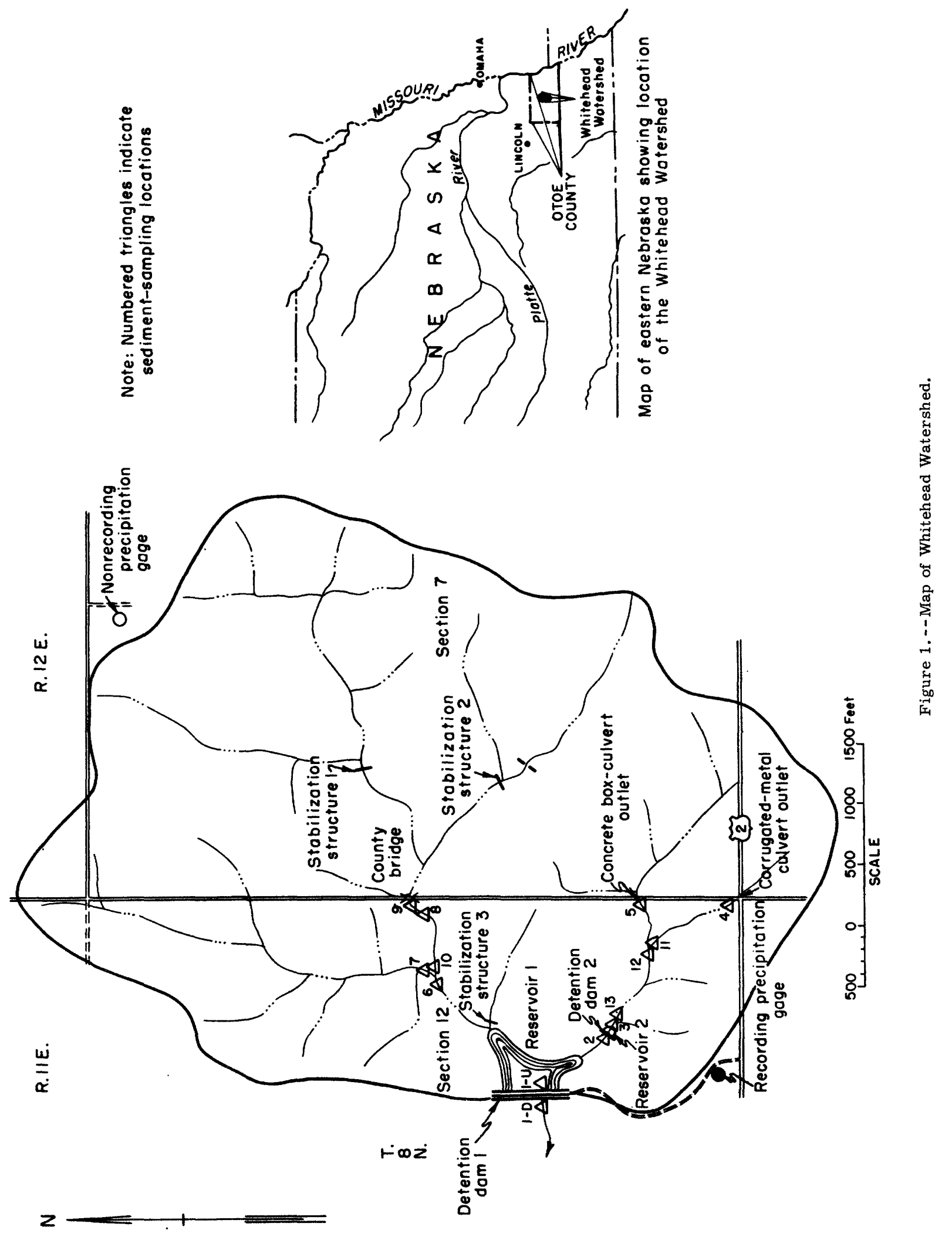




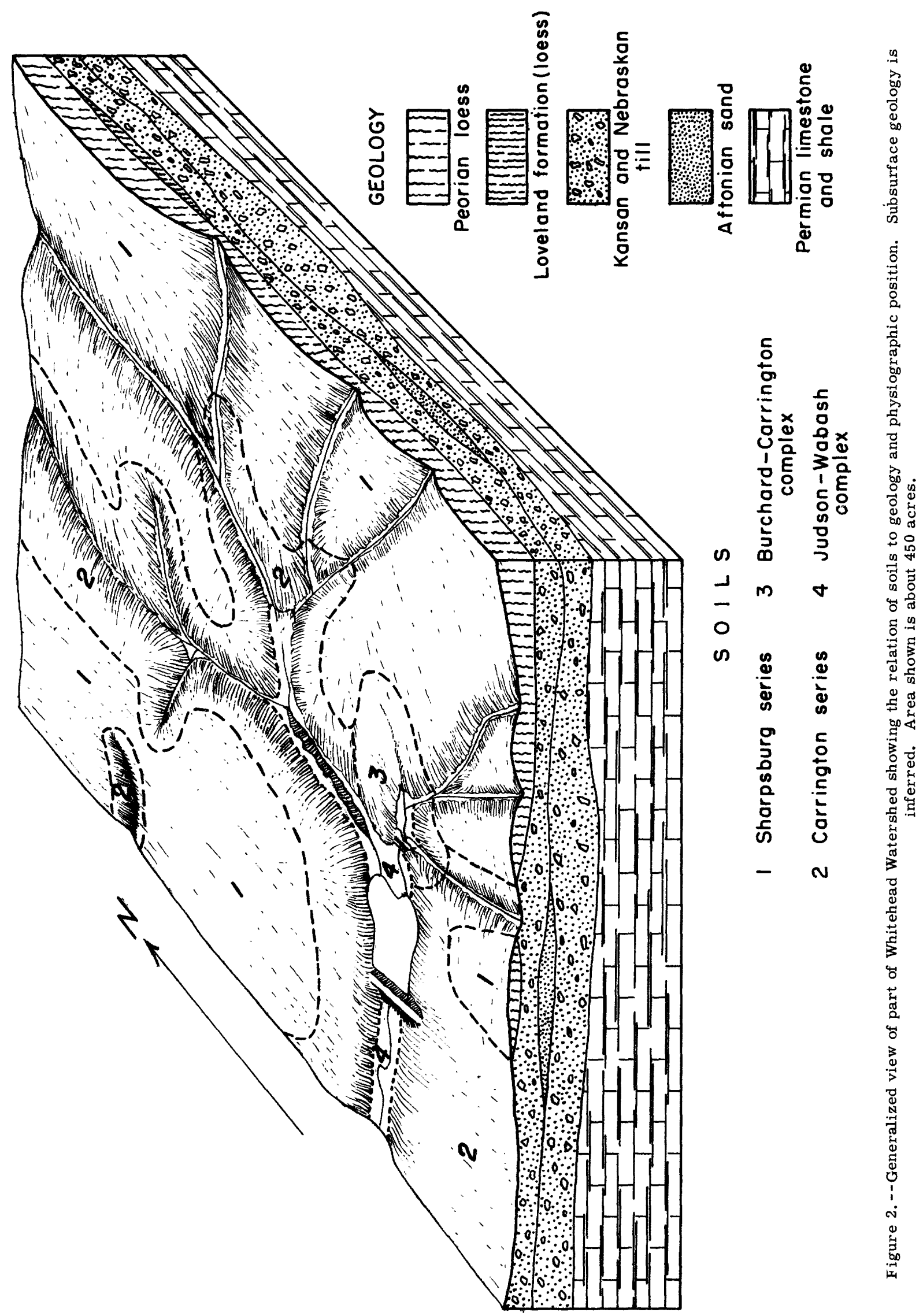


The major channels of the dendritic drainage system have very steep or vertical banks. The main channel leading into the northeast corner of reservoir 1 is incised 4 to 8 feet below the flood plain. Graded or level terraces that are constructed on nearly all the cultivated land and on some of the pastureland have modified the natural runoff patterns on most of the watershed.

\section{STRUCTURES AND RESERVOIRS}

Reservoir 1 (fig. 3) has a capacity of 125.6 acrefeet and a surface area of 13.0 acres at crest of emergency spillway, elevation 1,144 feet, mean sea level; at the top of the drop inlet, elevation 1, 134 feet, the capacity is 30.5 acre-feet and the surface area of the reservoir is 5.0 acres. Table 1 gives the area and capacity of 1-foot increments of el evation for this reservoir. Reservoir 2 (fig. 4) has a capacity of 4.25 acre-feet and a surface area of 1.29 acres at crest of emergency spillway, elevation 1,152 feet, mean sea level; at the top of the drop inlet, elevation $1,149.34$ feet, the capacity is about 1.94 acre-feet and the surface area of the reservoir is about 0.6 acre. Table 2 gives the area and capacity for this reservoir.

Drainage from approximately 350 acres flows directly into reservoir 1 . Channel-stabilization structures 1 and 2 exert a minor control on runoff from the northeast part of the watershed. Drainage from approximately 145 acres flows into reservoir 2; outflow from reservoir 2 flows into reservoir 1. Drainage from a very small area passes through stabilization structure 3 near the northeast corner of reservoir 1.

Table 1. - Area and capacily of reservoir 1 from survey of March 1955

\begin{tabular}{|c|c|c|c|}
\hline $\begin{array}{c}\text { Gage height } \\
(f t)\end{array}$ & $\begin{array}{l}\text { Elevation } \\
\text { (ft) }\end{array}$ & $\begin{array}{c}\text { Area } \\
\text { (acres) }\end{array}$ & $\begin{array}{l}\text { Capacity } \\
\text { (acre-ft) }\end{array}$ \\
\hline-11.00 & 1,122 & $\ldots \ldots \ldots \ldots \ldots$ & 0.5 \\
\hline-10.00 & 1,123 & $\ldots \ldots \ldots \ldots$ & 1.0 \\
\hline-9.00 & 1,124 & $\ldots \ldots \ldots \ldots$ & 2.0 \\
\hline-8.00 & 1,125 & $\ldots \ldots \ldots \ldots$ & 3.3 \\
\hline-7.00 & 1,126 & .. & 5.0 \\
\hline-6.00 & 1,127 & & 7. 0 \\
\hline-5.00 & 1,128 & . & 9.0 \\
\hline-4.00 & 1,129 & $\ldots \ldots \ldots$ & 12.0 \\
\hline-3.00 & 1,130 & $\ldots$ & 15.0 \\
\hline-2.00 & 1,131 & $\ldots \ldots \ldots \ldots$ & 18.0 \\
\hline-1.00 & 1,132 & 3.32 & 22.0 \\
\hline 0.00 & 1,133 & 4.15 & 26.0 \\
\hline 1.00 & 1,134 & 5.00 & 30.5 \\
\hline 2.00 & 1,135 & 5.90 & 35.5 \\
\hline 3.00 & 1,136 & 6.85 & 41.5 \\
\hline 4.00 & 1,137 & 7.89 & 48.1 \\
\hline 5.00 & 1,138 & 8.90 & 55.6 \\
\hline 6.00 & 1,139 & 9.98 & 64.0 \\
\hline 7.00 & 1,140 & 11.00 & 73.6 \\
\hline 8.00 & 1,141 & 12.20 & 84.4 \\
\hline 9.00 & 1,142 & 13.50 & 96.7 \\
\hline 10.00 & 1,143 & 14.64 & 110.3 \\
\hline 11.00 & 1,144 & 16.00 & 125.6 \\
\hline
\end{tabular}

Table 2.--Area and capacity of reservoir 2 from survey of March 1955

\begin{tabular}{c|l|c|c}
\hline $\begin{array}{c}\text { Gage height } \\
\text { (ft) }\end{array}$ & $\begin{array}{c}\text { Elevation } \\
\text { (ft) }\end{array}$ & $\begin{array}{c}\text { Area } \\
\text { (acres) }\end{array}$ & $\begin{array}{c}\text { Capacity } \\
\text { (acre-ft) }\end{array}$ \\
\hline 8.20 & $1,141.2$ & 0 & 0 \\
9.00 & 1,142 & .03 & .02 \\
10.00 & 1,143 & .10 & .09 \\
11.00 & 1,144 & .16 & .22 \\
12.00 & 1,145 & .22 & .41 \\
13.00 & 1,146 & .28 & .63 \\
& & & \\
14.00 & 1,147 & .34 & .92 \\
15.00 & 1,148 & .40 & 1.29 \\
16.00 & 1,149 & .50 & 1.74 \\
17.00 & 1,150 & .75 & 2.33 \\
18.00 & 1,151 & 1.03 & 3.15 \\
19.00 & 1,152 & 1.29 & 4.25 \\
\hline
\end{tabular}

The deposition of sediment in reservoir 1 is affected by detention dam 2 and, to a lesser degree, by the stabilization structures. Flow regulation through reservoir 2 is similar to that through reservoir 1 except that the time of detention is shorter because of a smaller reservoir capacity and a larger dis charge tube. The drop-inlet structure at reservoir 1 has a concrete riser having a rectangular opening 30 by 24 inches, and the discharge tube has a circular opening 18 inches in diameter. The drop-inlet structure at reservoir 2 has a metal riser 48 inches in diameter, and the discharge tube is 36 inches in diameter. Stabilization structures 1 and 2 have earth spillways; stabilization structure 3 has a metal drop-inlet arrangement similar to that of reservoir 2.

\section{METHOD OF OPERATION}

During the period April 1, 1955, to September 30, 1956, sediment was sampled at 14 locations in the Whitehead Watershed. (See fig. 1.) Outflow from reservoirs 1 and 2 was sampled at locations $1-\mathrm{D}, 1$ $\mathrm{U}$, and 2 ; and flow upstream from the reservoirs was sampled at locations 3 to 13 . Locations 10 to 13 were not used before June 30, 1956.

Outflow was sampled from reservoir 2 at the discharge-tube outlet and from reservoir 1 at the discharge-tube outlet and at the trash rack that protects the inlet of the discharge tube. Samples were collected at the outlets with a U. S. DH- 48 sampler (figs. 5 and 6) and at the trash rack with automatic suspended-sediment s a mplers in vertical stacks on the upstream corners of the rack (figs. 7 and 8). At reservoir 1 samples were also collected at the outlet with a continuous suspended-sediment sampler having the sampler intake nozzle in a fixed position inside the discharge tube.

Inflow to the reservoirs was sampled with a U. S. DH-48 sampler at locations $4,5,6,7,8,9,10,11$, 12 , and 13 and with automatic suspended-s ediment samplers at locations $3,6,7$, and 8 . The automatic samplers were placed in the channels so that the initial samples were collected when the flow reached a depth of about 0.7 foot. Automatic samplers were generally arranged in vertical stacks so that successive samples were obtained as the stage increased. Manual sampling at locations 5 and 9 was done by a 


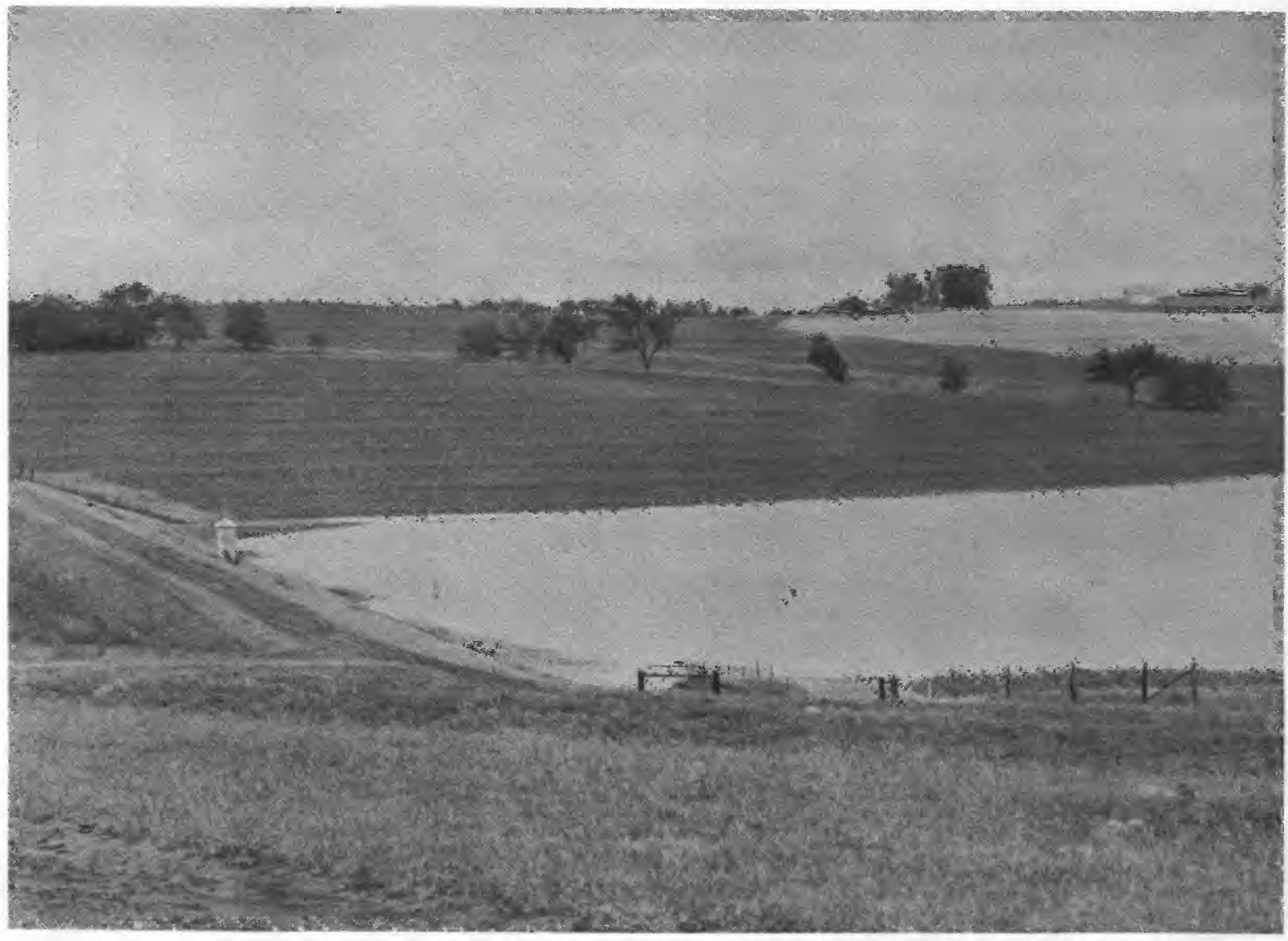

Figure 3.--Detention dam 1, Whitehead Watershed (June 24, 1955, reservoir elevation about 1, $140 \mathrm{ft}$ ).

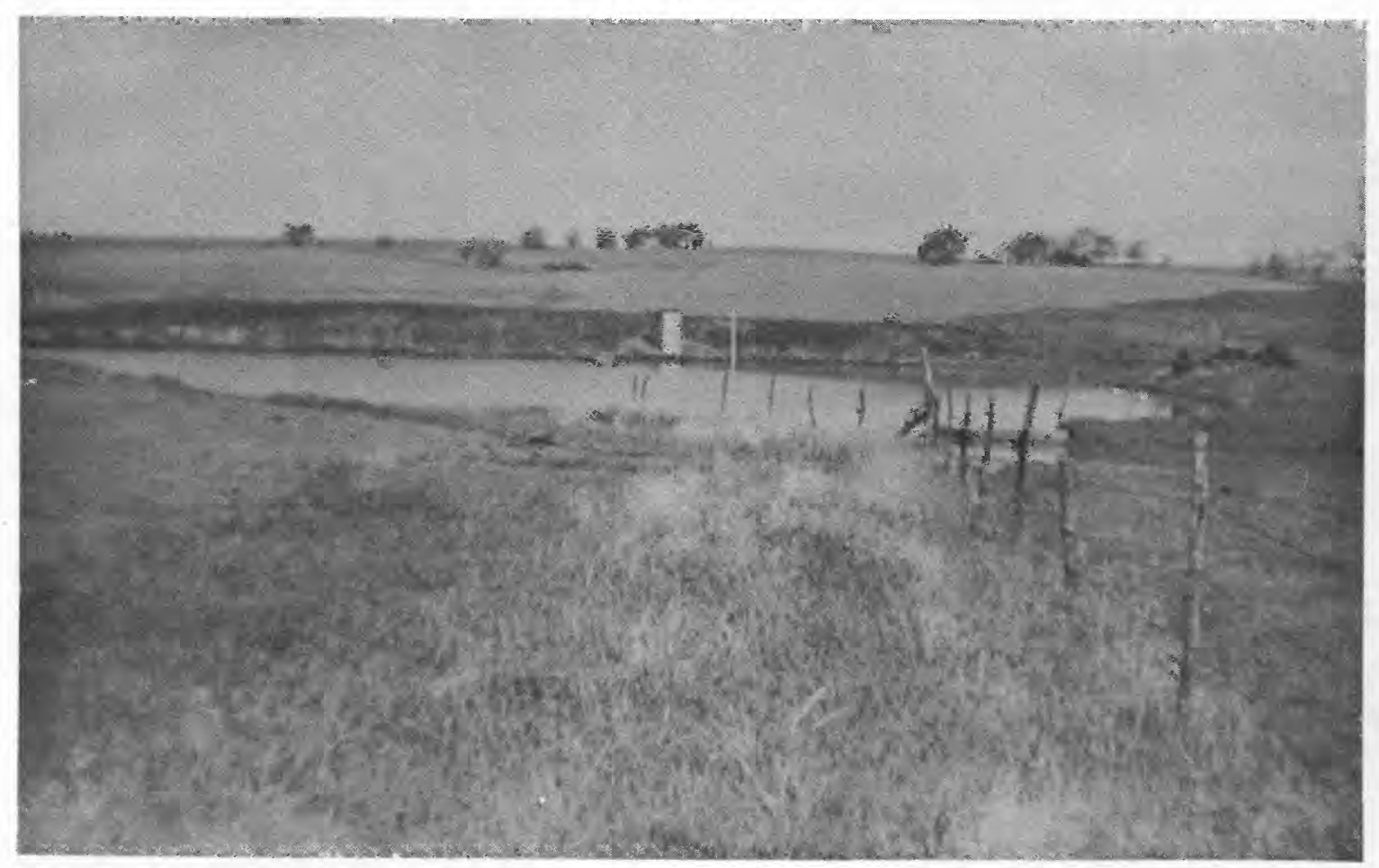

Figure 4.--Detention dam 2, Whitehead Watershed (May 5, 1955). 


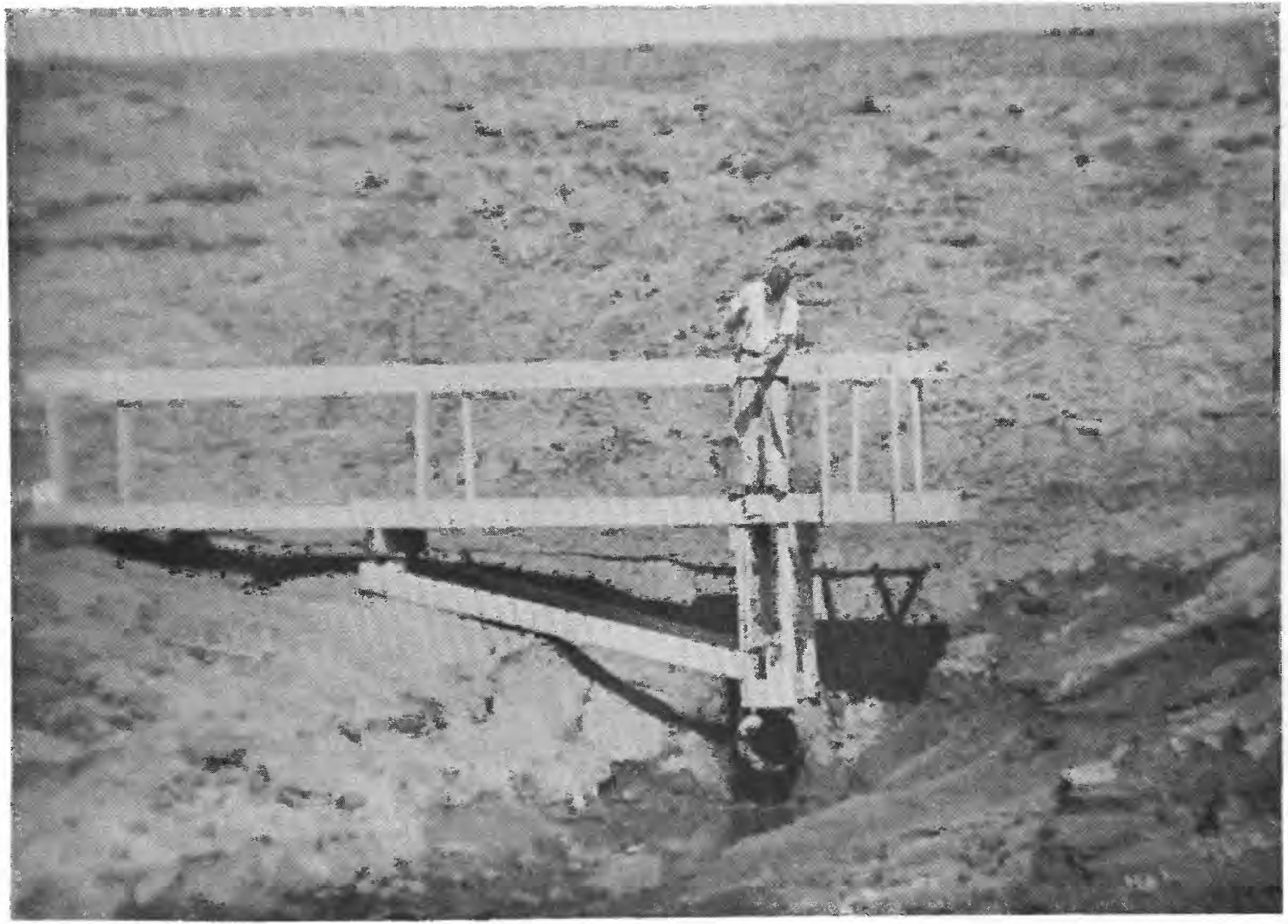

Figure 5.--Discharge-tube outlet, reservoir 1. Note sampler at end of discharge tube.

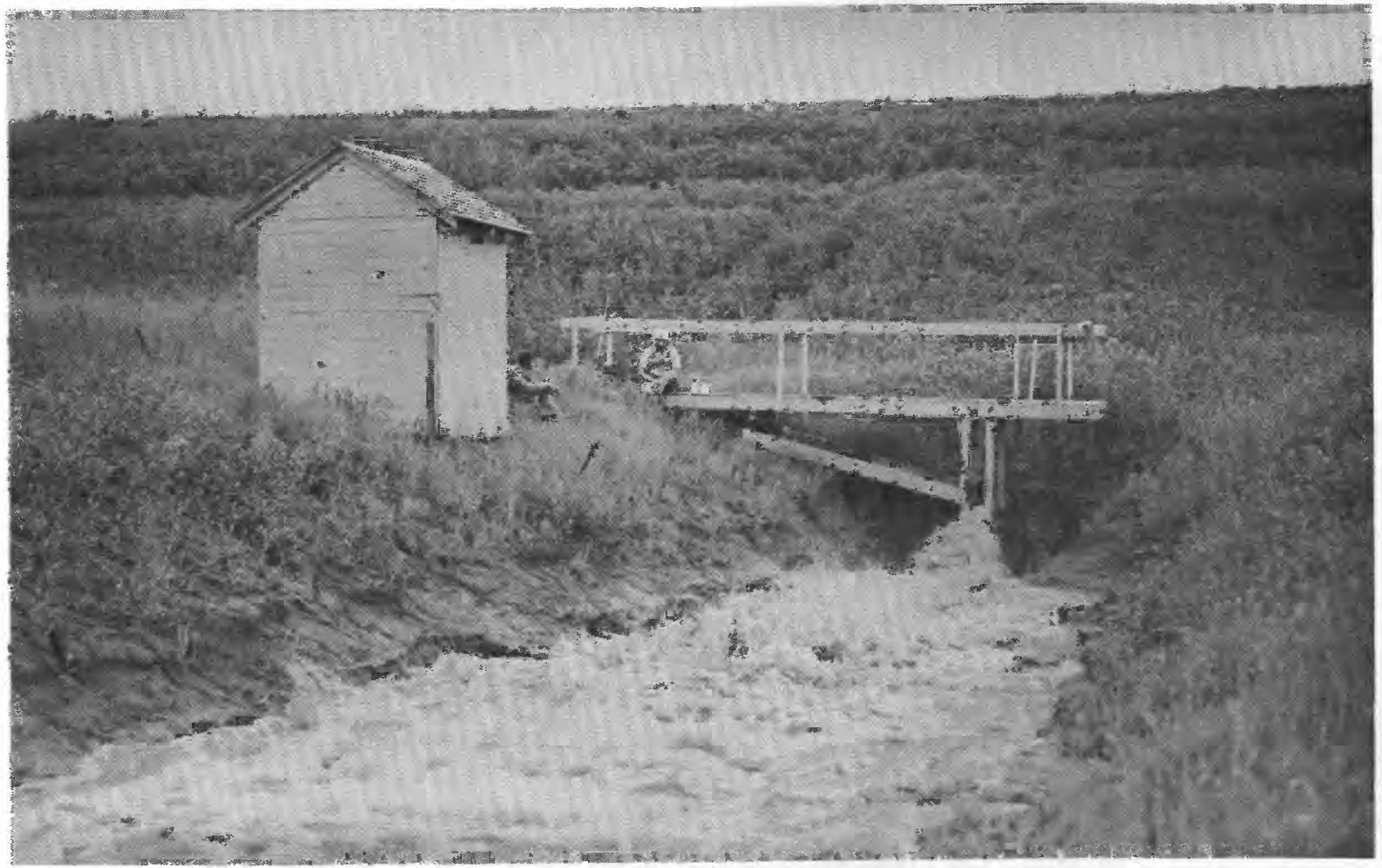

Figure 6.--Outflow from discharge tube, reservoir 1, June 24, 1955. Water discharge about 32 cfs. 


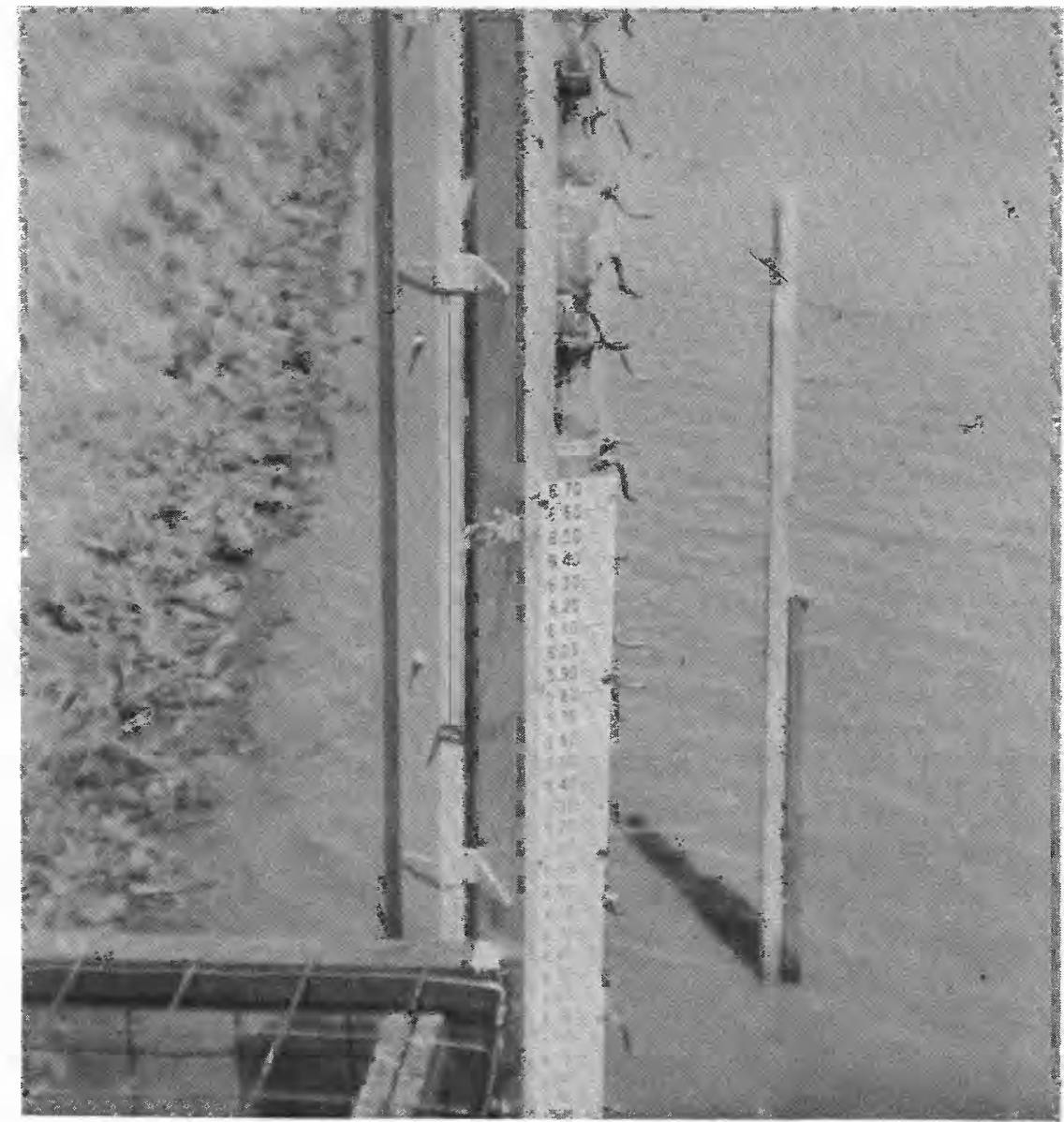

Figure 7.--Vertical stack of automatic suspended-sediment samplers at trash rack, reservoir 1.

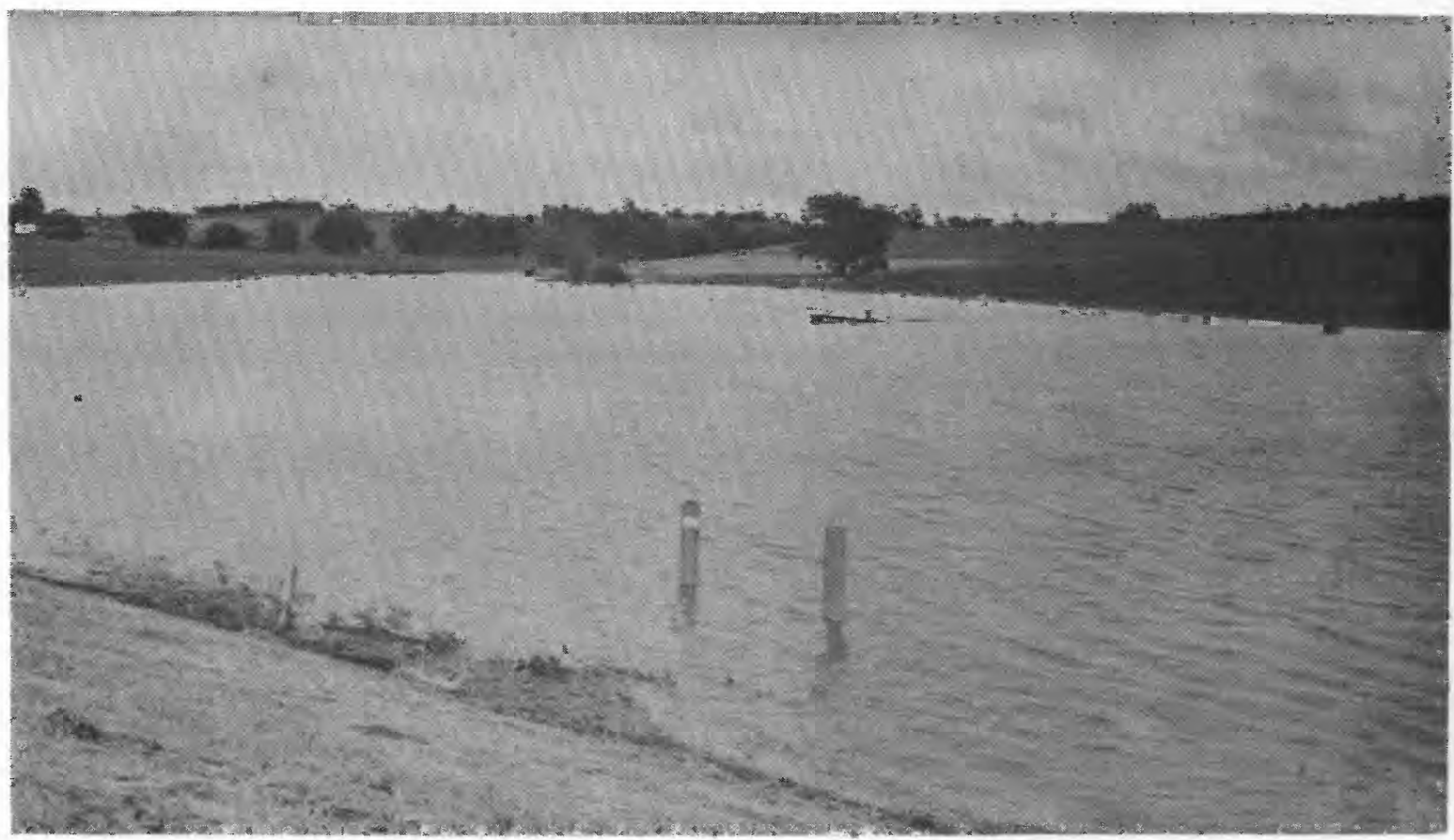

Figure 8. --Partly submerged vertical stack of automatic suspended-sediment samplers at trash rack, reservoir 1 (June 24, 1955, reservoir elevation about 1, $140 \mathrm{ft}$ ). 
local resident, who was assisted by Geological Survey personnel during periods of major runoff.

Precipitation was measured at a recording gage about a quarter of a mile south of reservoir 1 and at a nonrecording gage about 1 mile northeast of reservoir 1 (fig. 1).

\section{OUTFLOW PERIODS}

Seven periods of significant runoff and outflow occurred from April 1, 1955, to September 30, 1956. Table 3 gives the maximum gage height, total water discharge, and total sediment discharge at reservoir 1 for these periods.

Table 3.--Summary of outflow periods at reservoir 1

\begin{tabular}{|c|c|c|c|}
\hline Date & $\begin{array}{c}\text { Maximum } \\
\text { gage height } \\
\text { (ft) }\end{array}$ & $\begin{array}{c}\text { Water } \\
\text { discharge } \\
\text { (acre-ft) }\end{array}$ & \begin{tabular}{|c}
$\begin{array}{c}\text { Sediment } \\
\text { discharge } \\
\text { (tons) }\end{array}$ \\
\end{tabular} \\
\hline 1955 & & & \\
\hline Apr. $23-24 . \ldots \ldots$ & 2.31 & 9.32 & 10 \\
\hline Apr. $27-28 \ldots \ldots$ & 1. 21 & .60 & .9 \\
\hline June $24-26 \ldots \ldots$. & 7.81 & 59.7 & 135 \\
\hline June $28-29 \ldots \ldots \ldots$ & 2.03 & 6.74 & 11 \\
\hline Apr. 1 to Sept. 30 . & $\ldots \ldots \ldots$ & $\ldots \ldots \ldots$ & 156.9 \\
\hline 1956 & & & \\
\hline July $2-\overline{4 \ldots} \ldots \ldots$ & 2.07 & $\ldots \ldots \ldots$ & a 11 \\
\hline July 31-Aug. $3 \ldots$ & 2.03 & 5.95 & 1.0 \\
\hline Aug. $18-20, \ldots \ldots$ & 4.55 & 25.8 & 25 \\
\hline $\begin{array}{l}\text { Oct. } 1,1955 \text { to } \\
\text { Sept. } 30,1956 . .\end{array}$ & & & 37.0 \\
\hline
\end{tabular}

a Partly estimated.

The largest outflow period was June 24-26, 1955. In 12 hours, 4.30 inches of rain fell at a maximum intensity of about 2.00 inches per hour. At reservoir 1 , peak inflow was $653 \mathrm{cfs}$, peak outflow was $32.8 \mathrm{cfs}$, peak concentration of outflow was $3,400 \mathrm{ppm}$, maximum instantaneous sediment discharge was 275 tons per day, and total sediment discharge was 135 tons. Hydrographs of inflow and outflow, continuous concentration of outflow, accumulated precipitation, and some instantaneous concentrations of inflow are shown on figure 9. Gage-height trace, continuous concentration of outflow, accumulated precipitation, and some instantaneous concentrations of inflow at reservoir 2 for the period of June 23-24, 1955, are shown on figure 10. Samples at location 3 show that the peak concentration of inflow occurred during the initial sharp rise in stage.

On June 28-29, 1955, which was an outflow period of relatively minor significance, 0.85 inch of rain fell in 1.37 hours at a maximum 30-minute intensity of about 1.30 inches per hour. At reservoir 1, peak inflow was $95.0 \mathrm{cfs}$, peak outflow was $28.4 \mathrm{cfs}$, peak concentration of outflow was $1,530 \mathrm{ppm}$, maximum instantaneous sediment discharge was 115 tons per day, and total sediment discharge was 11 tons. Figure 11 shows hydrographs of inflow and outflow, continuous concentration of outflow, accumulated precipitation, and some instantaneous concentrations of inflow.
Very minor outflow occurred July 31 - A ug. 3, 1956. On July $31,1.97$ inches of rain fell between 5 and $8 \mathrm{p}, \mathrm{m}$., with 1.41 inches falling between 6 and 7 p. m. At reservoir 1, peak inflow was $131 \mathrm{cfs}$, peak outflow was $20.4 \mathrm{cfs}$, peak concentration of outflow was $148 \mathrm{ppm}$, maximum instantaneous sediment discharge was 7.3 tons per day, and total sediment discharge was 1.0 ton. Figure 12 shows hydrographs of inflow and outflow, continuous concentrations of outflow, and accumulated precipitation.

The second largest outflow period was Aug. 18-20, 1956. Total rainfall was 2.28 inches from 1 to 7 a. $\mathrm{m}$., with 1.90 inches falling between 1 and $3 \mathrm{a} . \mathrm{m}$. At reservoir 1, peak inflow was $241 \mathrm{cfs}$, peak outflow was $30.6 \mathrm{cfs}$, peak concentration of outflow was 1,110 ppm, maximum instantaneous sediment discharge was 93 tons per day, and total sediment discharge was 25 tons. Hydrographs of inflow and outflow, continuous concentration of outflow, and accumulated precipitation are shown in figure 13.

Particle-size analyses of suspended-sediment samples are given in tables 4-7. Table 4 lists samples of inflow to reservoir 1, table 5 lists samples of inflow to reservoir 2, table 6 lists samples of outflow from reservoir 2, and table 7 lists samples of outflow from reservoir 1 .

Particle-size distribution of inflow and outflow samples is shown graphically in figure 14 . The particle-size distribution of these samples shows that the outflow has a higher percentage of clay than the inflow, that most of the sand entering reservoir 2 is trapped, and that all the sand entering reservoir 1 is trapped.

Figure 15 shows the relationship between the percentage of sediment in a specific size class and the suspended-sediment concentration of inflow water to reservoirs 1 and 2. The curves in figure 15 indicate that, in general, the percentage of clay decreases and the percentage of silt increases as. the suspendedsediment concentration increases.

A comparison of suspended-sediment size analyses in native water and in distilled water with dispersing agent shows that the water is of such chemical quality as to induce significant flocculation of sediment during certain settling conditions. (See tables 4 to 7.) Results of chemical analyses of water samples collected concurrently with suspended-sediment samples ar e shown in table 8.

\section{GLOSSARY}

Automatic suspended-sediment sampler: a bottle equipped with intake nozzle and exhaust tube, which is mounted in a fixed position and which admits water-sediment mixture when the water rises to the level of the nozzle. A valve prevents entry of water after the bottle is about nine-tenths full.

Flocculation: the formation of larger sediment aggregates caused by coalescence of smaller particles that are subjected to certain physicochemical conditions. 


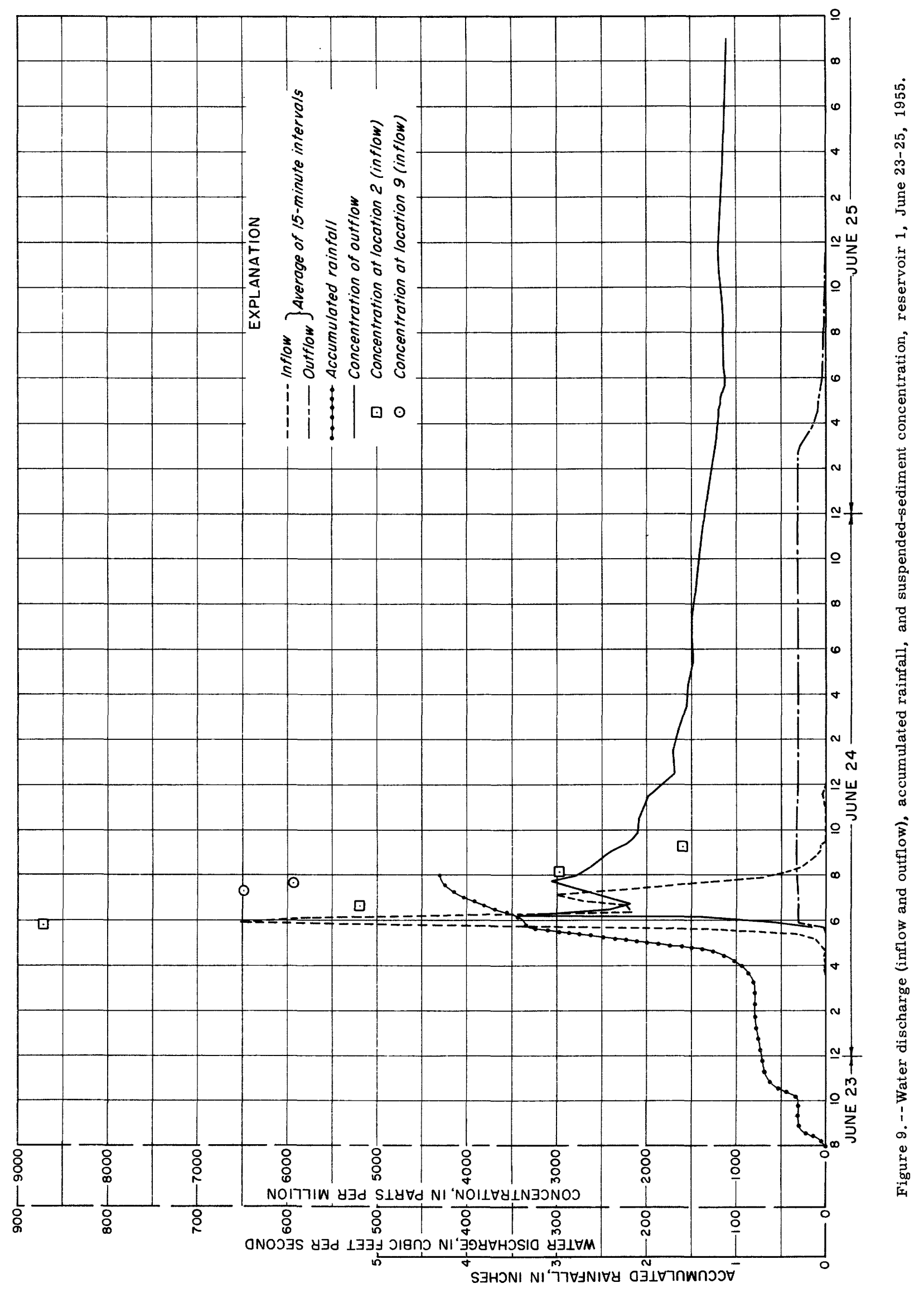




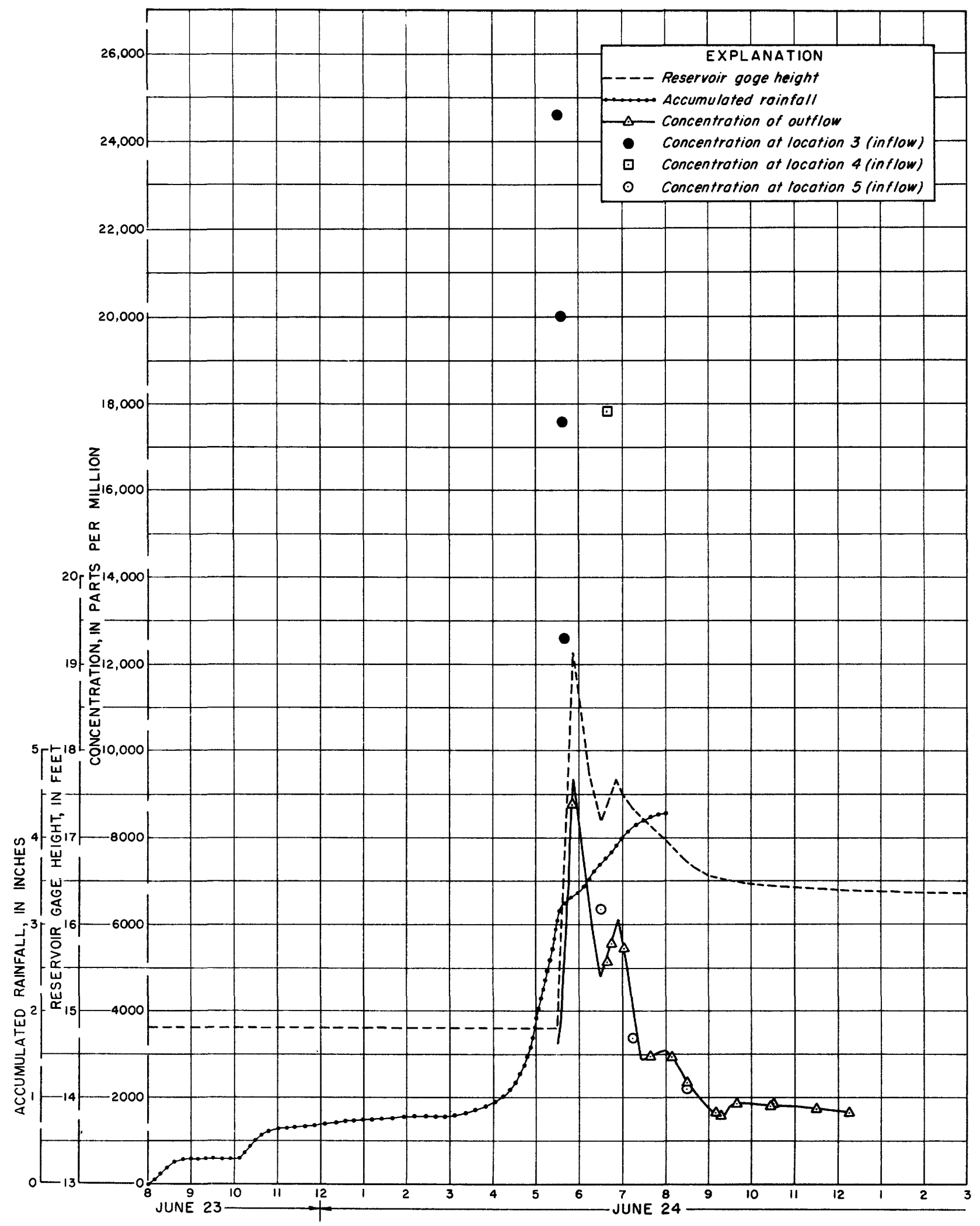

Figure 10.--Reservoir gage height, accumulated rainfall, and suspended-sediment concentration, reservoir 2, June 23-24, 1955. 


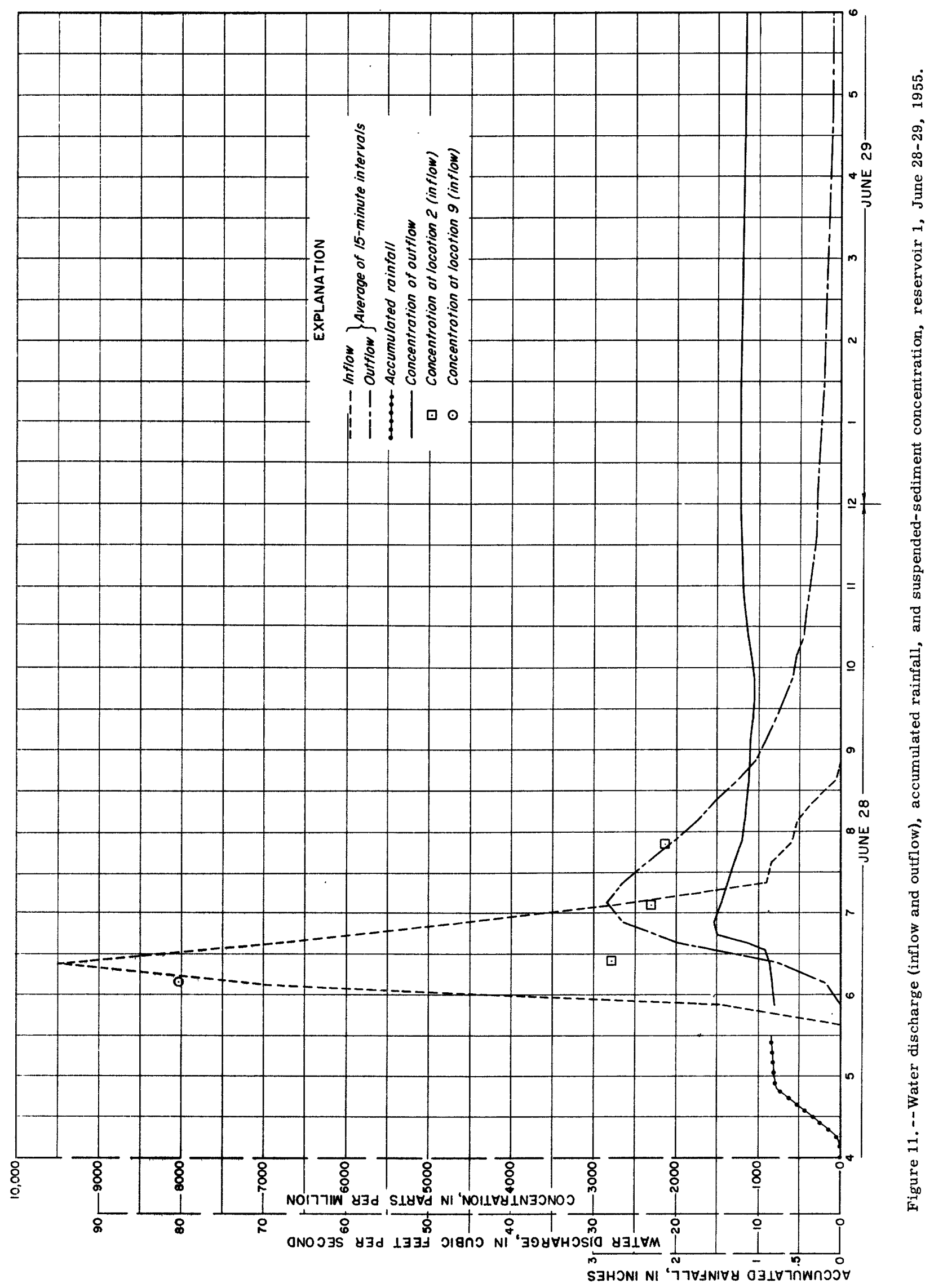




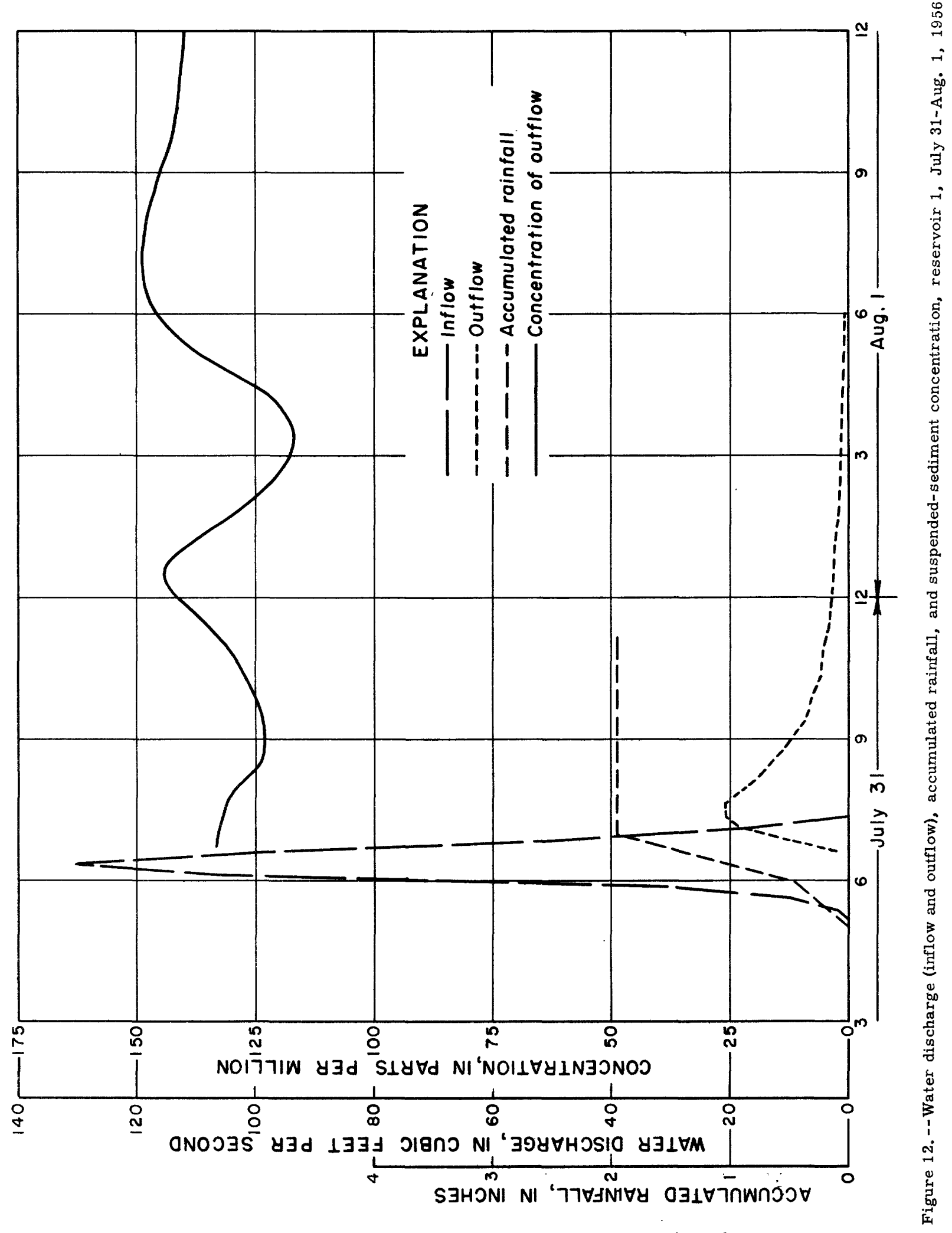




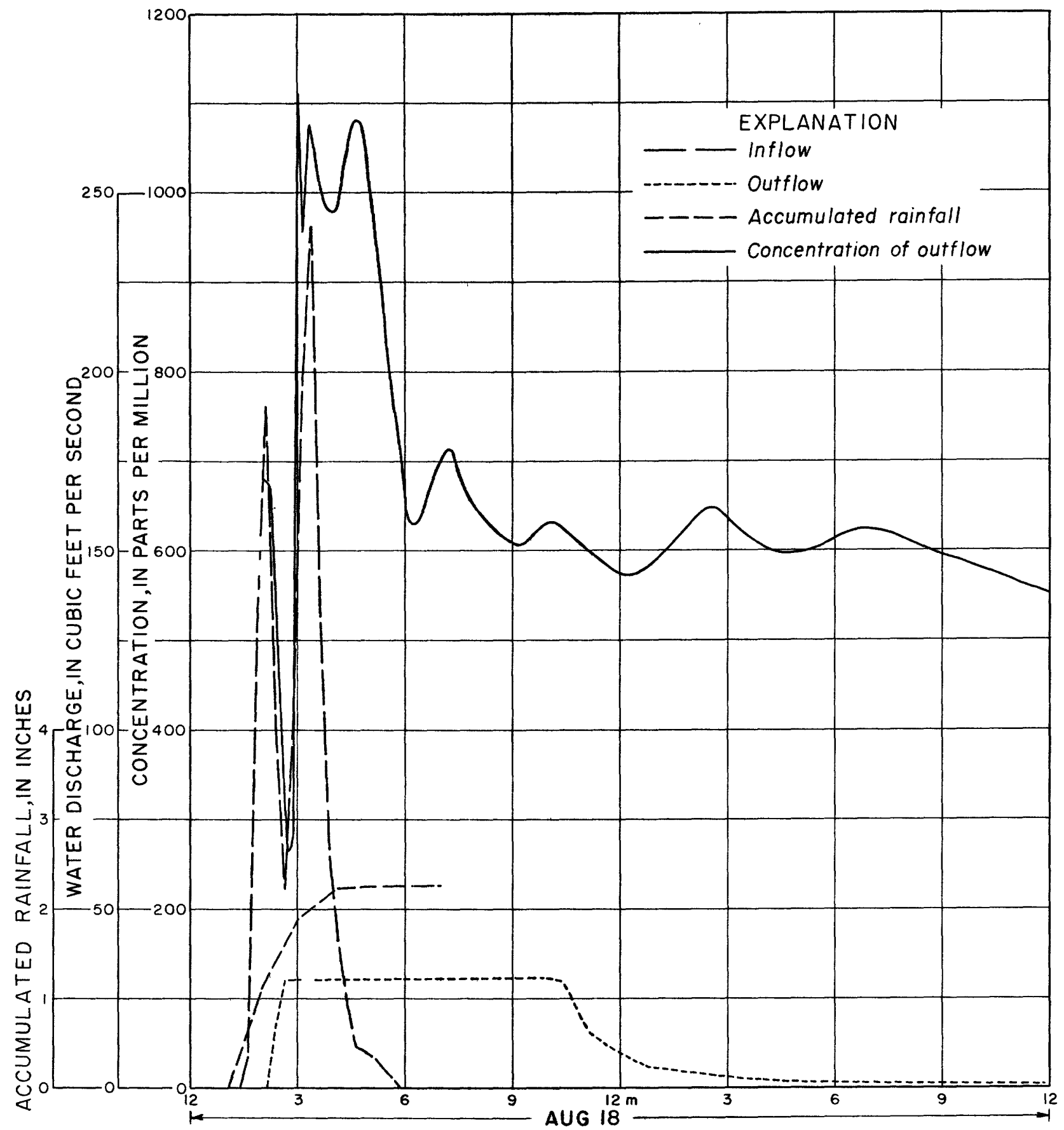

Figure 13. - Water discharge (inflow and outflow), accumulated rainfall, and suspended-sediment concentration, reservoir 1. Aug. 18, 1956. 


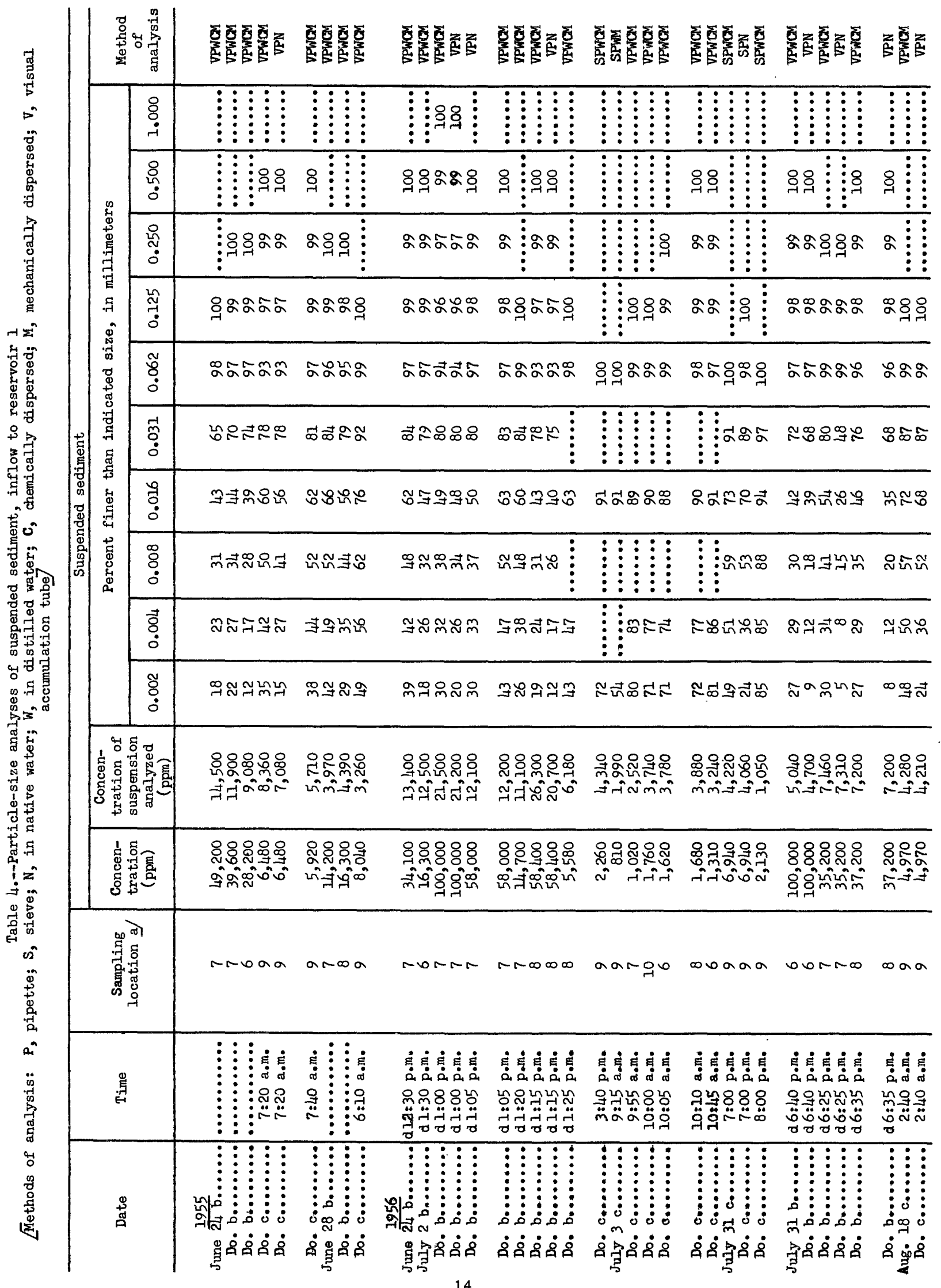




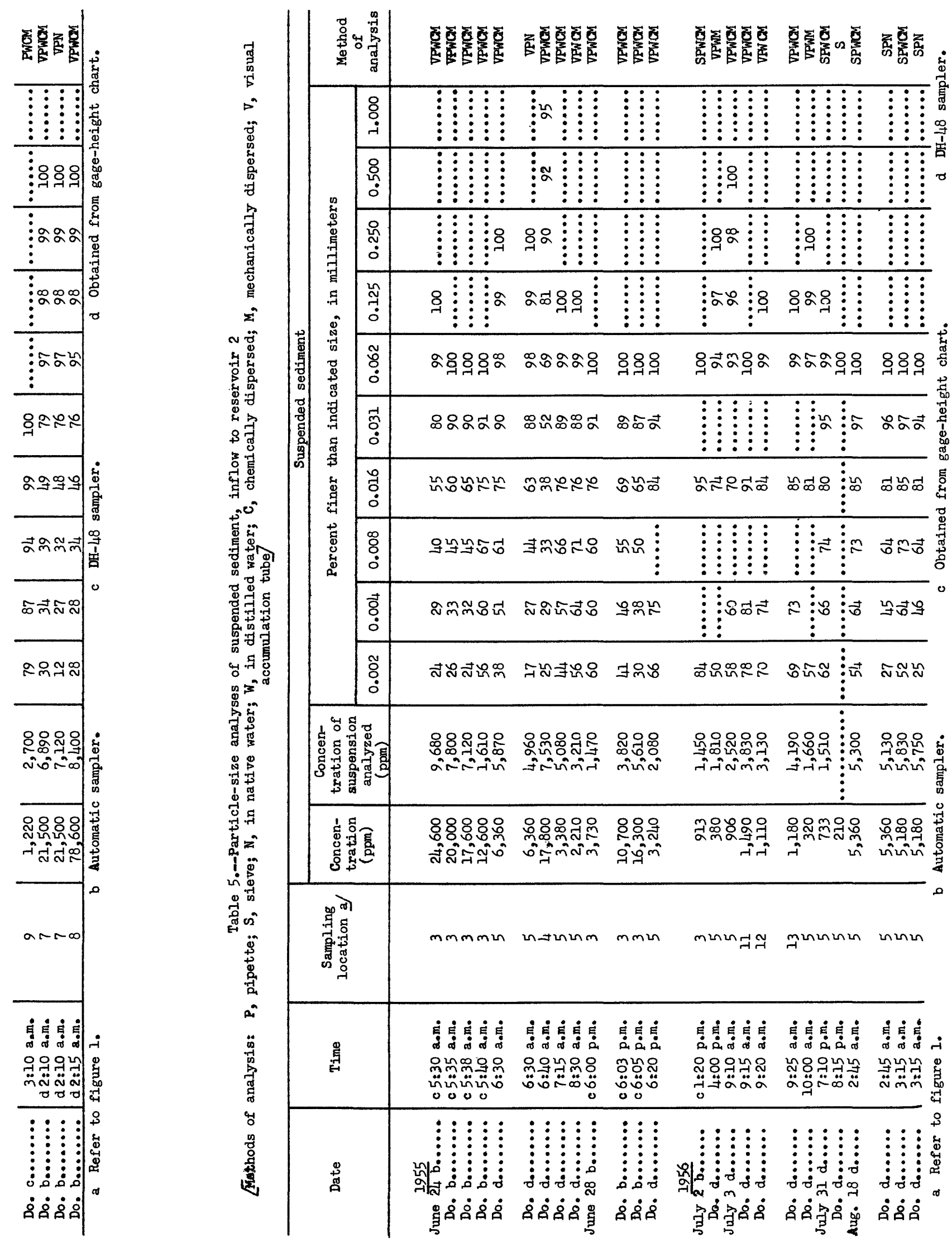




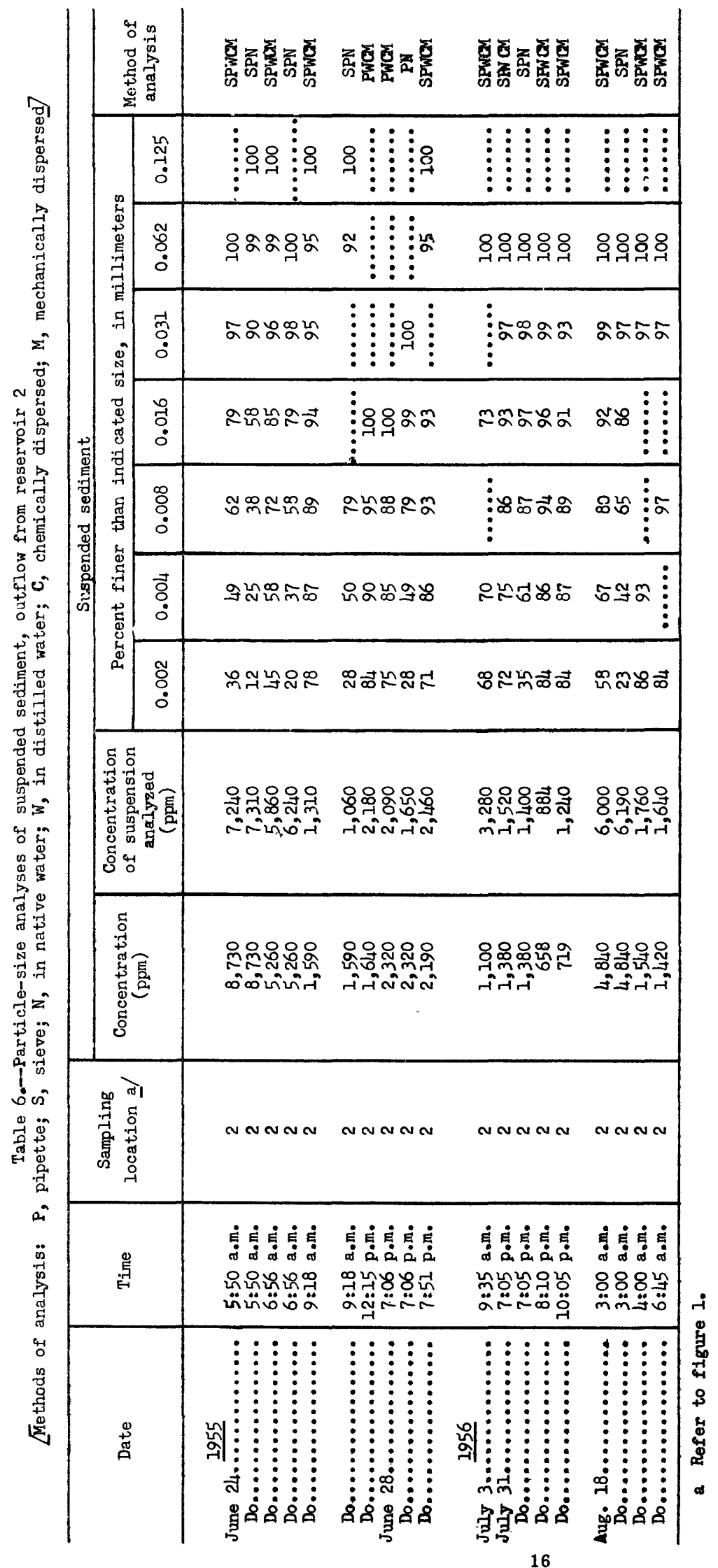




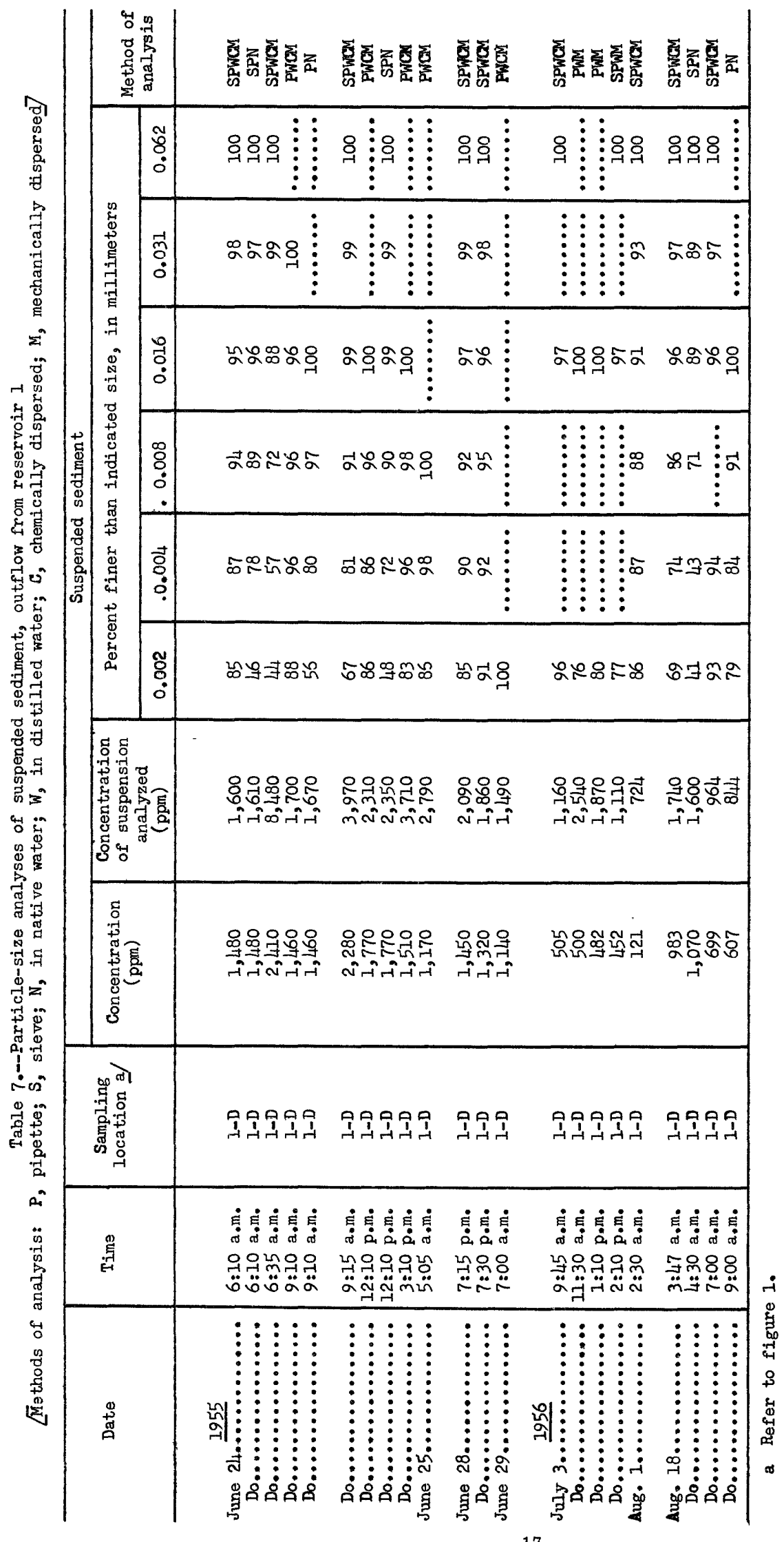




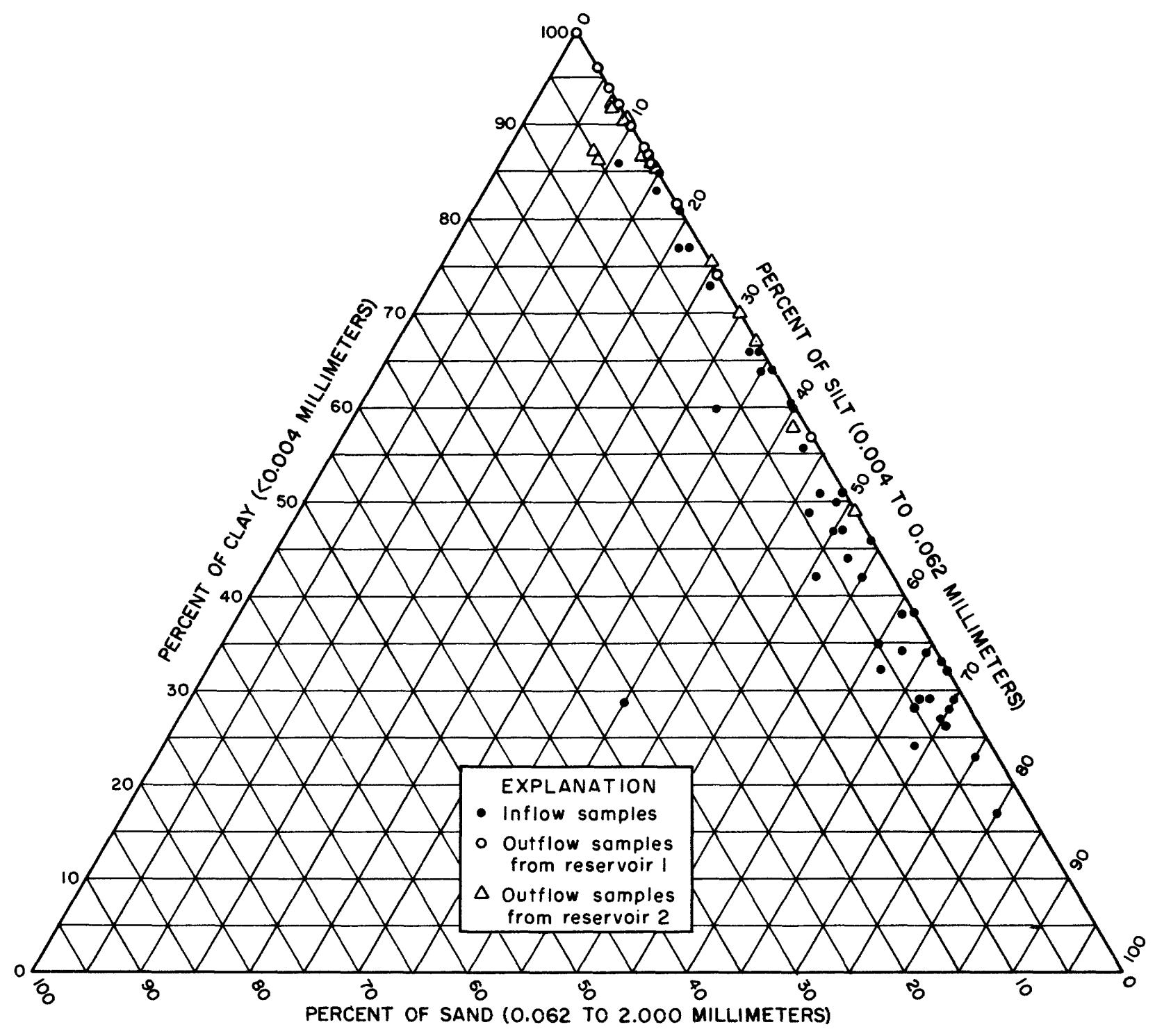

Figure 14. --Percentage of clay, silt, and sand in samples from Whitehead Watershed. 


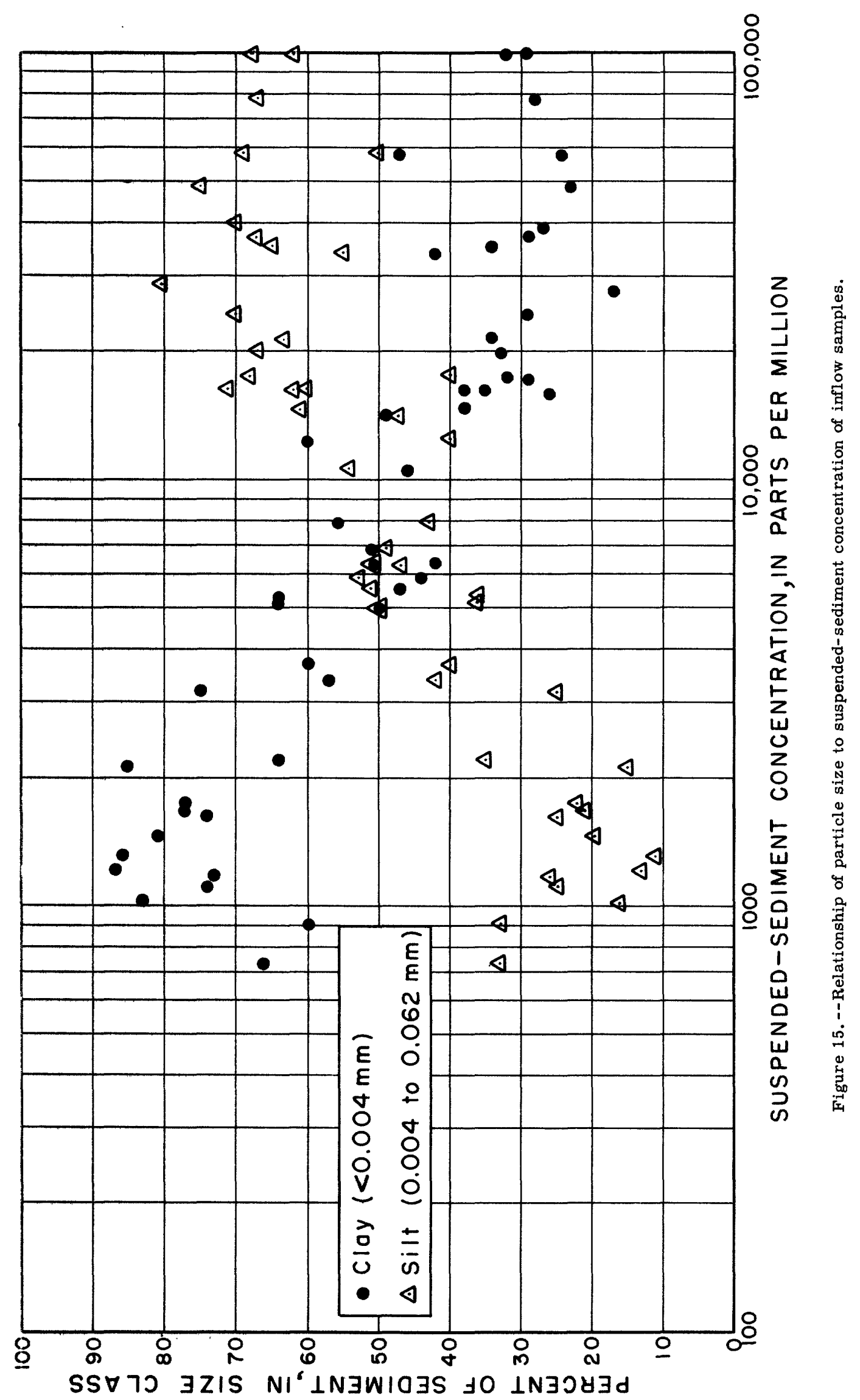




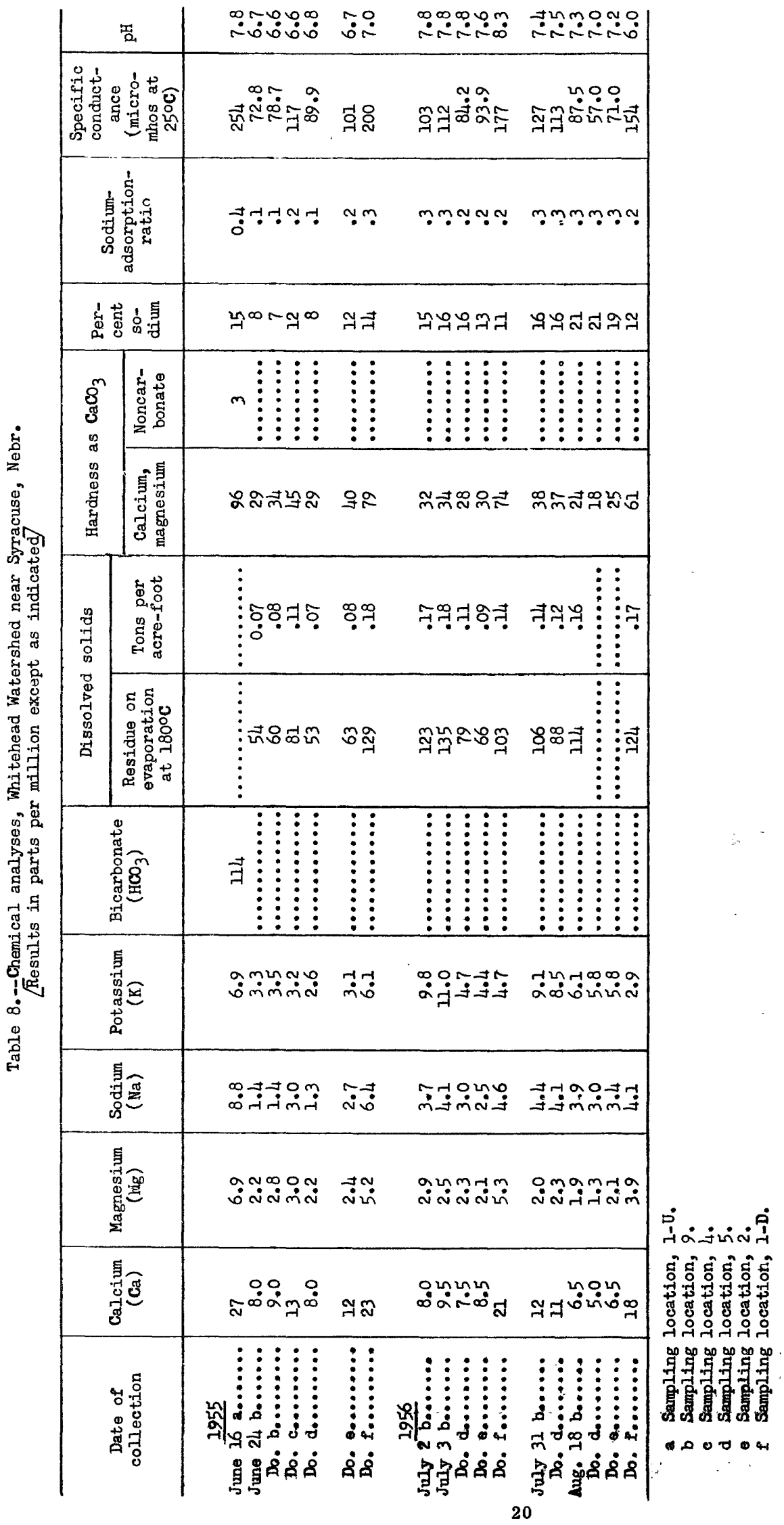


Instantaneous sediment discharge: the rate at which dry weight of sediment passes a section of a stream or conduit at a given instant.

Percent sodium: the ratio, expressed in percentage, of sodium to the sum of the positively charged ions (calcium, magnesium, sodium, and potassium)-all ions in equivalents per million.

Sodium-adsorption-ratio: a ratio for soil extracts and irrigation waters used to express the relative activity of sodium ions in exchange reactions with soil.

$$
\text { SAR }=\frac{\mathrm{Na}}{\sqrt{\frac{\mathrm{Ca}+\mathrm{Mg}}{2}}}
$$

The ionic concentrations are expressed in equivalents per million.

Suspended-sediment concentration: the weight of dry sediment per unit weight of water-sediment mixture, expressed as parts per million. 
